\title{
Fatty acid amide hydrolase (FAAH) inhibitor PF-3845 reduces viability, migration and invasiveness of human colon adenocarcinoma Colo-205 cell line: an in vitro study*
}

\author{
Andrzej Wasilewski ${ }^{1}$, Urszula Krajewska², Katarzyna Owczarek¹, Urszula Lewandowska and \\ Jakub Fichna ${ }^{1 凶}$ \\ 'Department of Biochemistry, Faculty of Medicine and 2Department of Pharmaceutical Biochemistry and Molecular Diagnostics, Faculty of \\ Pharmacy, Medical University of Lodz, Łódź, Poland
}

\begin{abstract}
Earlier reports suggest that the endocannabinoids may play a role of endogenous tumor growth modulators. In this study, we investigated whether inhibition of the enzymes involved in the synthesis and degradation of endocannabinoids may reduce colorectal cancer cell invasion and migration. The human colon adenocarcinoma Colo-205 cells were incubated with PF-3845, JZL184 and RHC-80267 (fatty acid amide hydrolase (FAAH), mono- (MAGL) and diacylglycerol lipase (DAGL) inhibitors, respectively) for $48 \mathrm{~h}$. The MTT colorimetric assay was performed to quantify cell viability. Next, Colo-205 cells were incubated with PF-3845 alone or with PF-3845 together with selected antagonists: AM 251, AM 630, SB 366791, RN 1734 and G-15 (CB, $\mathrm{CB}_{2}$, TRPV1, TRPV4 and GPR30 antagonists, respectively). Western blot assay was applied to identify the changes in $C_{1}$ and $C_{1} B_{2}$ receptor expression. Migration and invasion assays were employed to characterize the effect of PF-3845 on colorectal cancer cell invasion. We found that of all the inhibitors used, the FAAH inhibitor PF-3845 reduced the Colo205 cell line viability the most effectively $\left(\mathrm{IC}_{50}=52.55\right.$ $\mu \mathrm{M})$. We also showed that the effect of decreased cell viability was enhanced when Colo-205 cells were incubated with PF-3845 and RN-1734, a TRPV4 antagonist $\left(\mathrm{IC}_{50}=30.54 \mu \mathrm{M}\right)$. Western blot assay revealed significantly decreased $C B_{1}$ receptor expression levels, while $C^{2} B_{2}$ expression was increased in response to PF-3845 when compared to control. Furthermore, PF-3845 inhibited migration and invasion of Colo-205 cell line. These results suggest that pharmacological inhibition of FAAH and consequent enhancement of the endocannabinoid levels may reduce the colorectal cancer growth and progression.
\end{abstract}

Key words: cannabinoid receptors, Colo-205, colorectal cancer, invasion, migration

Received: 01 February, 2017; revised: 14 March, 2017; accepted: 14 April, 2017; available on-line: 30 August, 2017

\footnotetext{
更-mail: jakub.fichna@umed.lodz.pl
}

*These results were presented in part at the UEG Week 2016 congress (Vienna, Austria, October 16-18, 2016).

Abbreviations: AEA, anandamide; 2-AG, 2-arachidonoylglycerol; $\mathrm{CRC}$, colorectal cancer; $\mathrm{DAGL}$, diacylglycerol lipase; $\mathrm{EA}$, ethanolamine; FAAH, fatty acid amide hydrolase; GPER, G protein-coupled estrogen receptor 1; GPR30, G protein-coupled receptor 30; MAGL, monoacylglycerol lipase; NAPE, N-arachidonoyl phosphatidylethanolamine; PLD, phospholipase D; TRPV1, transient receptor potential vanilloid type 1

\section{INTRODUCTION}

Colorectal cancer (CRC) is the third most common cancer worldwide, and constitutes about $10 \%$ of all diagnosed cancers (Steward et al., 2014). There are over 1.4 million new cases of CRC worldwide each year, of which over $50 \%$ are found in developed countries; it is also estimated that there are almost 700000 deaths from CRC worldwide. Although various therapeutic strategies have been used in the treatment of CRC, including newly developed chemotherapeutic agents and monoclonal antibodies, often combined with partial surgical resection of colon, CRC still carries poor prognosis (Kelly et al., 2005). Thus, the real endeavor is to find new therapeutic agents providing more effective treatment.

The global data suggest that cannabinoids may inhibit tumor growth both in vitro and in animal tumor models. It has been demonstrated that natural and synthetic exogenous cannabinoids, as well as endocannabinoids inhibit tumor growth and progression of colon, breast, prostate and thyroid cancer, and leukemia by cytotoxic or cytostatic effects, induction of apoptosis, or inhibition of neoangiogenesis (Bifulco et al., 2006). The endocannabinoid system consists of "classical" $\mathrm{CB}_{1}$ (Matsuda et al., 1990; Gerard et al., 1991) and $\mathrm{CB}_{2}$ (Munro et al., 1993), and "non-classical" receptors, such as a transient receptor potential vanilloid type 1 (TRPV1) and type 4 (TRPV4), and a G protein-coupled receptor 30 (GPR30), also known as a $G$ protein-coupled estrogen receptor 1 (GPER), as well as their endogenous ligands and metabolizing enzymes (Pertwee 2006).

The two most studied endocannabinoids are anandamide (AEA) (Devane et al., 1992) and 2-arachidonoylglycerol (2-AG) (Mechoulam et al., 1995). Anandamide is mainly synthesized from its membrane phospholipid precursor $\mathrm{N}$-arachidonoyl phosphatidylethanolamine (NAPE) by phospholipase D (NAPE-PLD) (Liu et al., 2008). Termination of AEA signaling occurs through a time- and temperature-dependent uptake mechanism that controls its cellular trafficking and metabolism (Chicca et al., 2012). Anandamide is transported into the cell via a cell membrane carrier-mediated transporter and subsequently undergoes a rapid and almost complete intracellular degradation by fatty acid amide hydrolase (FAAH) into arachidonic acid and ethanolamine (EA) (Fowler, 2013; Day et al., 2001). 2-arachidonoylglycerol is synthesized from membrane phospholipids via sequential activation of phospholipase $\mathrm{C} \beta$ and diacylglycerol lipase (DAGL), and degraded by a monoacylglycerol lipase (MAGL). 
The aim of our study was to investigate the effect of selected inhibitors of the enzymes involved in the synthesis (RHC-80267) and degradation (JZL-184 and PF-3845) of AEA and 2-AG, on Colo-205 cell viability. Based on the data obtained in the in vitro MTT [3-(4,5-dimethylthiazolyl-2)-2,5-diphenyltetrazolium bromide] assay, the FAAH inhibitor PF-3845 $\left(\mathrm{IC}_{50}=52.55 \mu \mathrm{M}\right)$ was chosen for further analysis (Ahn et al., 2009). Next, we assessed the $\mathrm{IC}_{50}$ values in cells treated with PF-3845 alone, and co-incubated with selected cannabinoid receptor antagonists (AM 251, AM 630, SB 366791, RN 1734 and G-15 for $\mathrm{CB}_{1}, \mathrm{CB}_{2}$, TRPV1, TRPV4 and GPR30, respectively). To explore the mechanisms of action of PF-3845 in Colo-205 cell viability, we characterized the expression of $\mathrm{CB}_{1}$ and $\mathrm{CB}_{2}$ receptors by Western blot analysis. We also examined the effect of PF-3845 on Colo-205 cell migration and invasiveness. Collectively, our results show for the first time that PF-3845 may play a crucial role in inhibiting viability, migration and invasiveness of the Colo-205 cell line. Therefore, PF-3845 has the potential to be an efficient anti-cancer drug in therapeutic strategies for colorectal cancer.

\section{MATERIALS AND METHODS}

Culture conditions. Human colon adenocarcinoma Colo-205 cells were purchased from the European Collection of the Cell Cultures (ECACC). Colo-205 cells were cultured in RPMI-1640 medium supplemented with 10\% fetal bovine serum (FBS), $4 \mathrm{mM}$ L-glutamine, $50 \mathrm{U} / \mathrm{mL}$ penicillin, $50 \mu \mathrm{g} / \mathrm{mL}$ streptomycin, and $1 \%$<smiles>O=C(Nc1cccnc1)N1CCC(Cc2cccc(Oc3ccc(C(F)(F)F)cn3)c2)CC1</smiles>

PF-3845

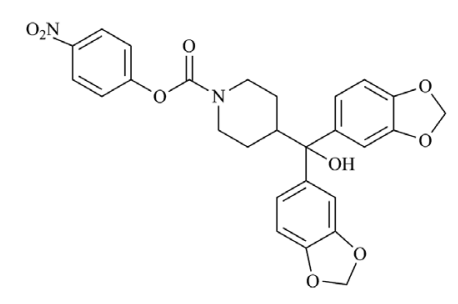

JZL-184

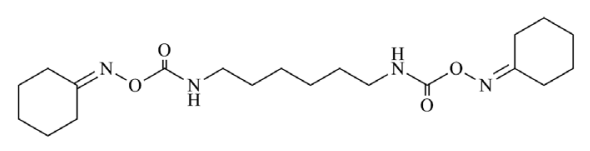

RHC-80267

Figure 1. Chemical formulas of the tested inhibitors: PF-3845, JZL-184 and RHC-80267. non-essential amino acids. Cells were grown in a humidified atmosphere of $5 \% \mathrm{CO}_{2}$ at $37^{\circ} \mathrm{C}$. All experiments were carried out between passages 5 and 15 .

Reagents. Enzyme inhibitors: PF-3845, JZL-184 and RHC-80267, selective for FAAH, MAGL, and DAGL, respectively (Fig. 1), the $\mathrm{CB}_{1}$ and $\mathrm{CB}_{2}$ receptor antagonists: AM 251 and AM 630, and the TRPV1, TRPV4 and GPR30 antagonists: SB 366791, RN 1734 and G-15, were purchased from Tocris Bioscience (Ellisville, MO). Inhibitors and antagonists were dissolved in dimethyl sulfoxide (DMSO) and then diluted to the final concentration with a serum-free medium. DMSO was purchased from Sigma-Aldrich, Inc. (St. Louis, Mo, USA). Cell culture media and supplements were purchased from Gibco (Life Technologies), except for amphotericin B (Biochrom AG, Berlin, Germany). Antibodies to $\mathrm{CB}_{1}$ (sc-20754), and $\mathrm{CB}_{2}$ (sc-25494) were purchased from Santa Cruz Biotechnology, Inc. (Dallas, TX, USA), and $\beta$-actin (A0545) was purchased from Sigma-Aldrich.

MTT assay. The effect of compounds on Colo-205 cell viability was assessed by the MT'T assay as described previously (Hansen et al., 1989). The assay principle is based on the fact that mitochondrial dehydrogenases of metabolically active cells reduce the tetrazolium ring to an insoluble MT'T formazan crystals. The resulting purple solution is spectrophotometrically measured and cell viability can be assessed. Cells were cultured in RPMI1640 medium supplemented with 10\% heat-inactivated FBS (Invitrogen, Paisley, UK), $4 \mathrm{mM}$ L-glutamine, and antibiotics $(50 \mathrm{U} / \mathrm{mL}$ penicillin, $50 \mu \mathrm{g} / \mathrm{mL}$ streptomycin), and 1\% non-essential amino acids. Exponentially growing colorectal cancer cells were seeded at $9.3 \times 10^{3}$ / well in a 96-well plate (Nunc, Roskilde, Denmark). Stock solutions of the analyzed compounds were freshly prepared in DMSO and diluted with complete culture medium to obtain the concentration range from $10^{-7}$ to $10^{-3} \mathrm{M}$. The final concentration of DMSO in the medium did not exceed $0.02 \%$. Cells were exposed to the test compound for $46 \mathrm{~h}$, then MT'T reagent (Sigma, St. Louis, USA) was added (5 mg/mL PBS) and incubation was continued for $2 \mathrm{~h}$. MTT-formazan crystals were dissolved in 20\% SDS and 50\% DMF at $\mathrm{pH} 4.7$ and absorbance was read at $570 \mathrm{~nm}$ with a Victor 3-plate reader (Perkin-Elmer, Turku, Finland). For control, cells were grown in the absence of compounds, but with their respective vehicle. Values of $\mathrm{IC}_{50}$ (the concentration of tested compounds required to reduce colon cancer cell survival fraction to $50 \%$ of control) were used as a measure of cellular sensitivity to a given treatment. Data points represent means from at least three independent experiments performed in triplicate.

Western blot analysis. The cells were lysed using a RIPA buffer (mammalian cell lysis kit, MCL-1; Sigma-Aldrich) with a protease inhibitor cocktail and centrifuged at $14000 \times \mathrm{g}$ for $20 \mathrm{~min}$ at $4^{\circ} \mathrm{C}$ supplemented with phosphatase and protease inhibitors. Cell lysates were stored at $-80^{\circ} \mathrm{C}$ until analysis. The samples protein concentration was assayed using the Bradford method. Aliquots of the lysates $(30 \mu \mathrm{g}$ of protein) were boiled for $5 \mathrm{~min}$, denatured and separated by 12\% SDS-polyacrylamide gel electrophoresis. Next, a Bio-Rad Trans-Blot system was used to transfer the proteins to a PVDF membrane. After the transfer, the membrane was blocked with $5 \%$ non-fat milk in Tris buffered saline containing $0.1 \%$ Tween 20 (TBS-T) and then incubated for two hours. The membrane was then washed in TBS-T and hybridized with primary rabbit $\mathrm{CB}_{1}$ and $\mathrm{CB}_{2}$ polyclonal antibodies (Santa Cruz Biotechnology, Dallas, TX, USA), which were diluted to a suitable concentration (1:200 - 
1:500) in TBS-T, for $16 \mathrm{~h}$. Additionally, the membranes were incubated with a goat polyclonal antibody specific for $\beta$-actin (1:100000 dilution) to use as a loading control. The membrane was washed six times with TBS-T and incubated with appropriate peroxidase-conjugated secondary antibody, and the protein bands were visualized using enhanced chemiluminescence Western blotting detection kit (Super Signal West Femto Reagent, Thermo Fisher Scientific, Rockford, IL, USA).

Migration assay. Cell migration assay was performed using the BD FalconTM 24-Multiwell Insert plate system (Becton Dickinson, Bedford, MA, USA), as described previously, with a slight modification (Lewandowska et al., 2013). Colo-205 cells were resuspended in a serumfree medium with or without PF-3845 $(0-100 \mu \mathrm{M})$ and plated onto the upper chamber at the densities of $1 \times 10^{5}$ per $500 \mu \mathrm{L}$. The lower chamber contained medium with $10 \%$ FBS as a chemoattractant. The chambers were incubated for $48 \mathrm{~h}$. After incubation, the non-migrated cells in the upper chamber were gently scraped away and adherent cells present on the lower surface of the insert were stained with crystal violet, photographed, and counted using the NIH ImageJ analysis software.

Invasion assay. Invasion studies were conducted using the Matrigel BM matrix assay developed for measurement of tumor cell invasiveness. We used BioCoat Matrigel invasion chambers (24-well cell culture inserts containing an 8.0- $\mu \mathrm{m}$ PET membrane with a uniform layer of Matrigel [Becton Dickinson, Bedford, MA]). Cells were resuspended in a serum-free medium with or without PF-3845 $(0-100 \mu \mathrm{M})$ and plated onto the upper chamber at the densities of $1 \times 10^{5}$ per $500 \mu \mathrm{L}$. The lower chamber contained medium with $10 \%$ FBS as a chemoattractant. The chambers were incubated for $72 \mathrm{~h}$. After incubation, the non-migrated cells in the upper chamber were gently scraped away and adherent cells present on the lower surface of the insert were stained with crystal violet, photographed, and counted using the NIH ImageJ analysis software.

Statistical analysis. Data are presented as means \pm standard deviation. Statistical significance was determined by one-way analysis of variance (ANOVA) followed by the Bonferroni $t$-test for multiple comparisons. The significance between two groups was determined using t-test. Statistical analyses were performed using PRISM 5.0 (GraphPad Software Inc., La Jolla, CA, USA). Differences resulting in a $p$-value of 0.05 or less were considered to be significant.

\section{RESULTS}

\section{PF-3845, but not JZL-184 and RHC-80267, significantly decreased the Colo-205 cell viability}

In our study, we first determined the influence of selected inhibitors: PF-3845, JZL-184 and RHC-80267 (selective for FAAH, MAGL and DAGL, respectively) on Colo-205 cell viability. PF-3845, at concentrations lower than $10 \mu \mathrm{M}$, had an inconsiderable effect (viability reduced by $7.73 \%$ at $10 \mu \mathrm{M}$ concentration) versus control, while it had a significant influence on Colo-205 cell viability $(p<0.001)$ at the concentration of $100 \mu \mathrm{M}(89.90 \%$ decrease in viability) (Fig. 2).

A significant effect for JZL-184 $(p<0.001)$ has been observed only at the concentration of $1000 \mu \mathrm{M}$, with reduced cell viability to $43.16 \%$. We did not observe any effect of JZL-184 at concentrations $0.1,1,10$, and 100 $\mu \mathrm{M}$ on the Colo-205 viability. Similarly, Colo-205 cell

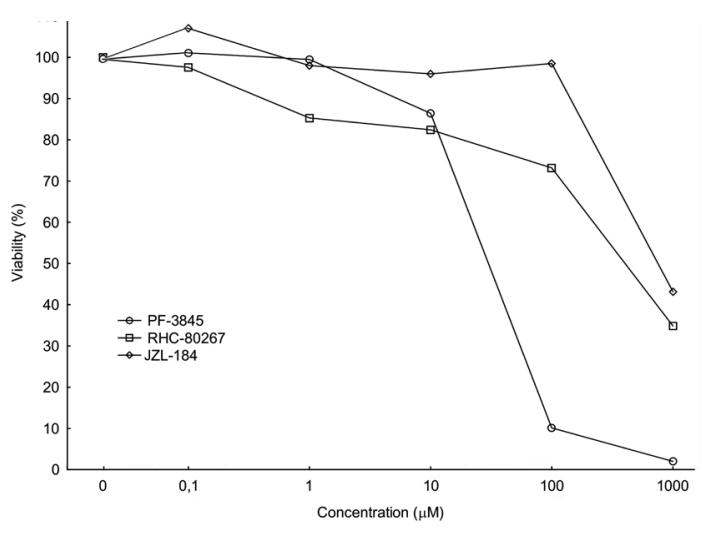

Figure 2. Survival curves for Colo-205 exposed to the tested compounds: PF-3845, JZL-184 and RHC-80267.

Cells $\left(9.3 \times 10^{3}\right.$ cells/well) were seeded in 96 -well culture plates. After $24 \mathrm{~h}$, the cells were treated with PF-3845, JZL-184 or RHC$80267(0,0.1,1.0,10,100,1000 \mu \mathrm{M})$ for another $48 \mathrm{~h}$. Cell viability was measured by MTT assay. Each point represents the mean of 5-10 independent determinations. Standard deviations were excluded for clarity and did not exceed $12 \%$ of the mean value for each point.

viability did not clearly decrease in response to RHC80267 at the concentrations lower than $10 \mu \mathrm{M}$. The effect of RHC-80267 reached a statistically significant decrease at 100 and $1000 \mu \mathrm{M}(p<0.001)$, with reduction in cell viability to 73.40 and $34.88 \%$, respectively.

Based on the MT'T test results and calculated $\mathrm{IC}_{50}$ values for inhibitors: 52.55, 900.89 and $638.95 \mu \mathrm{M}$ for PF-3845, JZL-184 and RHC-80267, respectively, the former was selected for further studies as the most efficient in decreasing the Colo-205 cell viability. Thus, we next compared the $\mathrm{IC}_{50}$ values in cells treated with PF-3845 alone, and PF-3845 with selected receptor antagonists (Fig. 3). The calculated $\mathrm{IC}_{50}$ values were lower when cells were treated with PF-3845+antagonist than with PF-3845 alone. Namely, PF-3845 co-incubated with a TRPV4 antagonist RN 1734 displayed the highest potency to reduce Colo-205 cell viability, with an $\mathrm{IC}_{50}$ value of $30.54 \mu \mathrm{M}$ (vs. $\mathrm{IC}_{50}=51.38 \mu \mathrm{M}$ for PF-3845 alone). The $\mathrm{IC}_{50}$ values for PF-3845 + AM 251, PF-3845+SB-366791, and PF-3845+AM-630 were 37.51, 38.49 , and $40.20 \mu \mathrm{M}$, respectively. On the contrary, PF-3845+G-15 (GPR30 antagonist) exhibited slightly

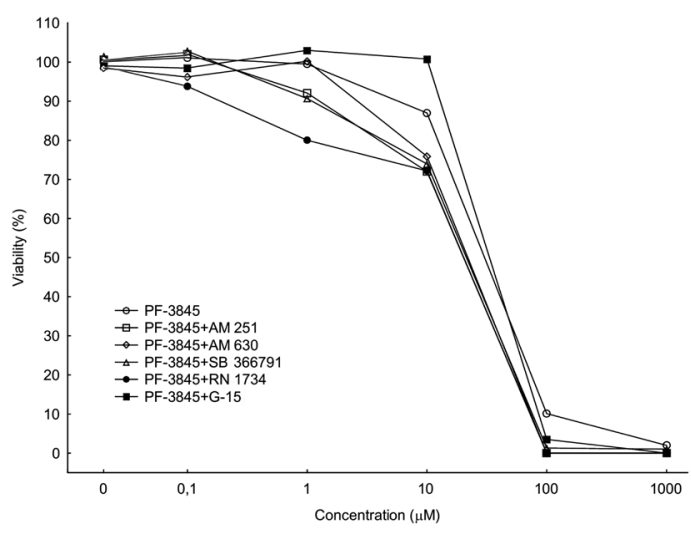

Figure 3. Survival curves for Colo-205 exposed to FAAH inhibitor PF-3845 alone or co-incubated with selected antagonists: AM 251 (CB1 receptor antagonist), AM 630 (CB2), SB 366791 (TRPV1), RN 1734 (TRPV4) and G-15 (GPR30).

Each point represents mean of 5 independent determinations. Standard deviations were excluded for clarity and did not exceed $12 \%$ of the mean value for each point. 

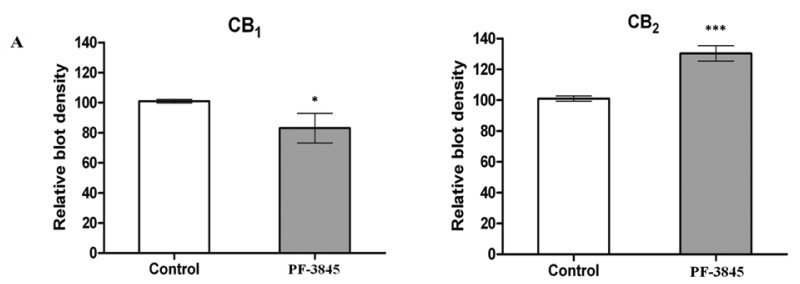

B

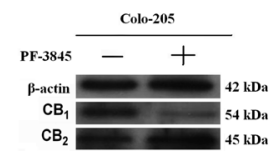

Figure 4. Effect of PF-3845 on CB1 and CB2 receptor expression in the Colo-205 cells.

(A) Cells were treated with PF-3845 for $48 \mathrm{~h}$ and subjected to Western blot analysis. PF-3845 decreased expression of $C B_{1}$ and increased expression of $C_{2}$ receptor. (B) $\beta$-actin in the cell lysate is shown as control. Each blot is representative of at least three other blots. Density values of the bands are graphically expressed relative to control. Data are shown as mean \pm S.D. $(n=4)$. Significance of differences between means: ${ }^{*} p<0.05$ versus control; ${ }^{* * *} p<0.001$ versus control.

higher $\mathrm{IC}_{50}$ value $(55.89 \mu \mathrm{M})$ when compared with $\mathrm{IC}_{50}$ of PF-3845 alone $\left(\mathrm{IC}_{50}=51.38 \mu \mathrm{M}\right)$.

\section{Expression of $C B_{1}$ receptors decreased, while $C B_{2}$ increased in the Colo-205 cells}

Anandamide is a known $\mathrm{CB}_{1}$ and $\mathrm{CB}_{2}$ receptor agonist (Reggio et al., 2000). To examine the effect of the inhibition of FAAH by PF-3845 on the expression of $\mathrm{CB}_{1}$ and $\mathrm{CB}_{2}$ receptors in the Colo-205 cells, Western blot analysis was used. As shown in Fig. $4 \mathrm{~A}$ and $4 \mathrm{~B}$, when the cells were treated with PF-3845 at the concentration of $52.55 \mu \mathrm{M}\left(\mathrm{IC}_{50}\right.$ value determined for PF-3845 alone in the previous stage), a significant $(p<0.05)$ decrease was observed in expression of the $\mathrm{CB}_{1}$ receptor. On the contrary, $\mathrm{CB}_{2}$ expression level significantly increased $(p<0.001)$ in response to PF-3845 when compared with the untreated control. Taken together, these results demonstrate that PF-3845 affects expression of the key receptors of endocannabinoid pathway.

\section{PF-3845 significantly reduces migration and invasiveness of the Colo-205 cells}

To investigate the activity of PF-3845 against tumor metastasis, we investigated its effects on migration of the Colo-205 cells. As illustrated in Fig. 5, the data from the migration assay indicated that migration of the Colo-205 cells was clearly inhibited by PF-3845 in a concentration-dependent manner (Fig. 5A and 5B). Suppression of the Colo-205 migration reached 49.57, 81.73, 96.4 and $100 \%$ versus control at PF-3845 concentrations of $25 \mu \mathrm{M}$, $50 \mu \mathrm{M}, 75 \mu \mathrm{M}$ and $100 \mu \mathrm{M}$, respectively.

The loss of cell-cell adhesion capacity allows tumor cells to dissociate from the primary tumor mass leading to the spread of metastatic cancers. In the next stage, we decided to test whether PF-3845 displays the potency to reduce colorectal cancer cell invasion. An invasion assay in Matrigel-coated transwell chamber indicated that PF-3845 inhibited invasiveness of the Colo-205 cells (Fig. 6A and 6B). At the lowest concentration tested $(25 \mu \mathrm{M})$, PF-3845 was not efficient in inhibiting Colo205 invasiveness and the reduction was only of $5.53 \%$ vs. control, whereas at 50, 75 and $100 \mu \mathrm{M}$ concentrations it reached $71.28 \%, 88.50 \%$, and $100 \%$ versus control, respectively.

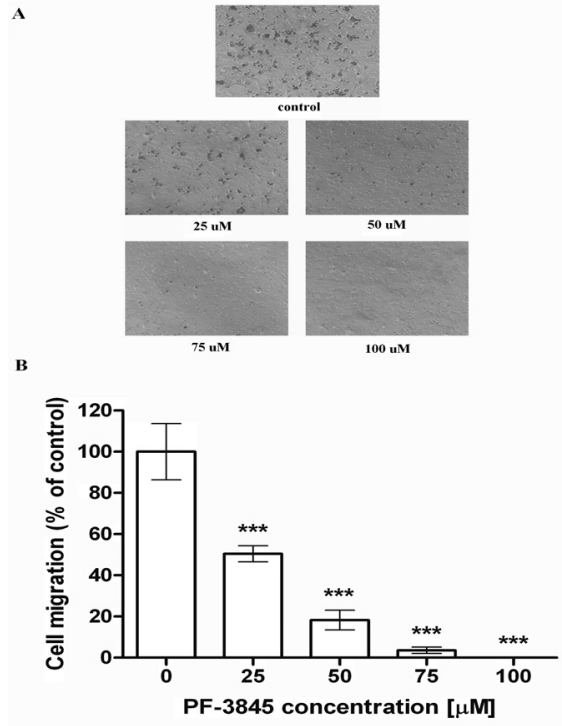

Figure 5. Inhibition of Colo-205 cell migration by PF-3845 in the concentration range of 0 to $100 \mu \mathrm{M}$.

Migration studies were conducted using BD Falcon ${ }^{\mathrm{TM}}$ 24-Multiwell Insert plate system. Total area of inserts with crystal violet-stained cells was photographed and counted using the NIH ImageJ analysis software. (A) Representative images obtained for Colo-205 are shown above graphs. Initial magnification: $\times 200$. (B) Each value on the graph represents the mean value \pm S.D., $n=3$ independent experiments. Significance of differences between means: ${ }^{* *} p<0.001$ versus control.

\section{DISCUSSION}

Here, we have demonstrated that modulation of the activity of enzymes involved in the endocannabinoid turnover translates into cancer cell viability, migration and metastasis. This may have an important implication

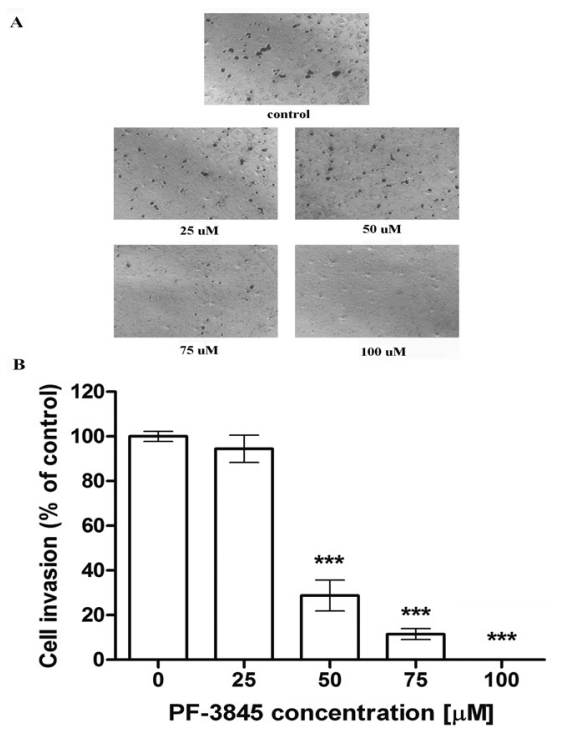

Figure 6. Inhibition of Colo-205 cell invasiveness by PF-3845 in the concentration range of 0 to $100 \mu \mathrm{M}$.

Invasion studies were conducted using the Matrigel BM matrix assay developed for measurement of tumor cell invasiveness. Total area of inserts with crystal violet-stained cells was photographed and measured using the NIH ImageJ analysis software. (A) Representative images obtained for Colo-205 are shown above graphs. Initial magnification: $\times 200$. (B) Each value on the graph represents the mean value \pm S.D., $n=3$ independent experiments. Significance of differences between means: ${ }^{* *} p<0.001$ versus control. 
for development of anticancer strategies targeting the endocannabinoid system.

We have observed that the Colo-205 cell viability was reduced after treatment with $\mathrm{PF}-3845$. It is a potent and selective inhibitor of the FAAH enzyme which hydrolyzes AEA into arachidonic acid and EA (Bifulco et al., 2004; De Lago et al., 2006; Endsley et al., 2007). Blocking of the endocannabinoid degradation has been proven to be effective for eradication of other cancer cell types. For example, Matas and coworkers (2007) had observed that the non-selective FAAH inhibitor URB597 induces cell death in neuroblastoma cells. Noteworthy, this effect was obtained by preventing generation of EA from AEA, and not by increasing the AEA level or signaling through the $\mathrm{CB}$ receptors. What may be important also for our study, Matas and coworkers (2007) had shown that EA exerts an anti-apoptotic action; therefore, a pharmacologically-induced decrease of EA levels may deteriorate cancer cell viability. Earlier reports indicate that the inhibition of FAAH may induce cell death also by activating the nuclear factor (erythroid-derived 2)-like 2 (NFE2L2 or NRF2)/antioxidant responsive element (ARE) signaling pathway and the heme oxygenase-1 (HO-1) induction and transcription (Ranger et al., 2009). These pathways can be taken into consideration when explaining the anti-cancer action of PF-3845 observed in our study. Of note, we did not observe any statistically significant effect of JZL-184, a MAGL inhibitor, on reduction of the Colo-205 cell viability. This is in contrast to Ye and coworkers (2011) et al. who had demonstrated inhibition of the tumor cell growth and invasion via knockdown of MAGL by JZL-184 and siRNA in human CRC cells.

In search for underlying pathways, we have assessed the influence of Colo-205 cell incubation with PF-3845 alone and in the presence of "classical" $\left(\mathrm{CB}_{1}\right.$ and $\left.\mathrm{CB}_{2}\right)$ and "non-classical" (TRPV1, TRPV4, GPR30) cannabinoid receptor antagonists (AM 251, AM 630, SB 366791 , RN 1734 and G-15, respectively). Interestingly, we have found that co-incubation with the receptor antagonists, except for G-15, reduced the Colo-205 cell viability, with the highest potency displayed by RN 1734. In contrast, a slight, but not statistically significant antagonizing effect of G-15 was observed. Our data may suggest that the effect of PF-3845 on the Colo-205 cell viability is not necessarily $\mathrm{CB}_{1}, \mathrm{CB}_{2}$, TRPV1 or TRPV4-dependent. Further studies are needed to verify whether a different receptor type, either "classical" or "non-classical" is involved.

Noteworthy, the higher potency to reduce Colo-205 cell viability by PF-3845 in the presence of the antagonists may be related to a dual action of this inhibitor; namely, PF-3845 inhibits FAAH and may be also involved in blocking of the AEA uptake through actions on the plasma membrane transport protein (Björklund et al., 2014; Day et al., 2001). It is known that AEA activates the TRPV1 capsaicin receptor and leads to an increase of intracellular $\mathrm{Ca}^{2+}$-levels (Ralevic et al., 2001). Recently, TRPV1 has been found to contribute to AEA transport into endothelial cells in a $\mathrm{Ca}^{2+}$-independent manner and to be involved in the pro-angiogenic effect of AEA in the endothelial cells (Hofmann et al., 2014). Therefore, a complex interplay of the effects mediated by receptor and uptake proteins in the presence of PF3845 and these protein inhibitors needs to be acknowledged. It has been also shown previously that the increase of cannabinoid receptor expression may lead to activation of the pro-survival signal of the Akt kinase, and as a result, the treatment does not induce apoptosis, unless the Akt activation is blocked (Cudaback et al.,
2010). Whether this is the case for PF-3845 and Colo205 , especially in view of the cannabinoid receptor expression data discussed below, remains to be determined.

The study presented here was also designed to estimate the effect of PF-3845 on $\mathrm{CB}_{1}$ and $\mathrm{CB}_{2}$ receptor expression level. Here, we found that the $\mathrm{CB}_{1}$ level decreased, while $\mathrm{CB}_{2}$ expression was increased in cells incubated with the FAAH inhibitor. There are only a few studies focused on the expression of the cannabinoid receptors in tumor cells. An increased expression of $\mathrm{CB}_{1}$ and/or $\mathrm{CB}_{2}$ has been demonstrated in mantle cell lymphoma (Ek et al., 2002; Islam et al., 2003), acute myeloid leukemia (Alberich et al., 2004), breast cancer (Caffarel et al., 2006), and prostate cancer cell lines. Of note, $\mathrm{CB}_{1}$ receptor expression by tumor cells was associated with poor prognosis in patients with prostate cancer (Cipriano et al., 2013). Downregulation of $\mathrm{CB}_{1}$ receptor expression was observed in neoplastic epithelial cells from colon cancer biopsies (Cianchi et al., 2008). Jung et al. had demonstrated that $\mathrm{CB}_{1}$ receptor expression was correlated with distant metastasis in CRC, but not with tumor invasion and lymph node metastasis, and $\mathrm{CB}_{1}$ expression was downregulated as CRC progressed to a highly advanced stage of disease (Jung et al., 2013). Gustafsson et al. had shown that high intensity of the $\mathrm{CB}_{1}$ receptor was correlated with a shorter survival time than with a low $\mathrm{CB}_{1}$ receptor intensity (Gustafsson et al., 2011). Wang et al. had shown that $\mathrm{CB}_{1}$ expression was silenced in human CRC due to high $(77 \%)$ methylation of the $\mathrm{CB}_{1}$ promoter (Wang et al., 2008). To summarize, whether the PF-3845-induced changes in the cannabinoid receptor expression result from adaptation mechanisms upon modulation of the endocannabinoid levels and whether these can be efficiently used in colon cancer treatment needs further investigation.

In this work, we have also investigated the effects of PF-3845 on migration ability of the Colo-205 cell line. We have found that PF-3845 decreases migration of tumor cells by $49.57 \%$, already at the concentration of $25 \mu \mathrm{M}$. This correlates with a general observation that cannabinoids are anti-migratory agents in cancer cell lines. For example, Met-fluoro-anandamide (MetF-AEA), an analog of AEA, caused a $\mathrm{CB}_{1}$ receptordependent antimigratory effect in breast cancer cells. Met-F-AEA inhibited the activity of the GTPase, RhoA, and led to translocation of RhoA to the cytosol, which caused changes in the actin cytoskeleton (Laezza et al., 2008). Another study had shown that cell migration initiated by mast cells was reduced by $2-A G$ and WIN$55,212-2$ in a $\mathrm{CB}_{1}$ receptor dependent manner (Rudolph et al., 2008). Noteworthy, AEA and HU-210 were shown to block the migration of colon carcinoma cells with low $\mathrm{CB}_{2}$ receptor expression. On the contrary, as shown for cannabidiol (CBD), its effect on inhibition of the U87 human glioma cell migration was not mediated via the classical $\mathrm{CB}$ receptors or a $\mathrm{G}$ protein-coupled signalingrelated mechanism (Massi et al., 2004; Vaccani et al., 2005).

The invasion capacity of cancer cells determines their penetration power into surrounding tissues, a crucial early step in the metastatic cascade. Here, we investigated the influence of PF-3845 on invasiveness of the Colo205 cell line and observed that blocking FAAH efficiently inhibits cell invasion. Similarly, another study reported that increase in the $2-A G$ levels significantly inhibits invasion of the human androgen-independent prostate cancer cells, PC-3 and DU-145. The effect is comparable to that of WIN55,212-2 and (R)-(+)-methanandamide, 
which decrease PC-3 and DU-145 cell invasion in a $\mathrm{CB}_{1}{ }^{-}$ dependent manner (Nithipatikom et al., 2004).

Interestingly, PF-3845 was efficient in inhibiting migration of the Colo-205 cells at non-cytotoxic concentrations, whereas the inhibition of invasiveness was observed at concentrations equal to IC50 or higher. The clinical significance of this observation needs further investigation.

\section{CONCLUSION}

Our study demonstrates that the FAAH blocker PF3845, but not MAGL and DAGL blockers JZL-184 and RHC-80267, effectively decreases viability, migration and invasiveness of the Colo-205 cell line. These results suggest that modulation of the endocannabinoid turnover through inhibition of their hydrolysis could be a potential anticancer strategy. However, more studies are needed to clarify long-term effects of FAAH blockers on cancer cells and translating these into clinical conditions.

\section{Author contributions}

Wasilewski A, Krajewska U, Lewandowska $U$ and Fichna J conceived and designed the experiments; Wasilewski A, Krajewska U, Owczarek K and Lewandowska U. performed the experiments; Wasilewski A, Krajewska $\mathrm{U}$, Lewandowska $U$ and Fichna $J$ analyzed the data; all authors drafted the article and made critical revisions related to the intellectual content of the manuscript, and approved the final version of the paper.

\section{Conflicts of interest}

The authors declare no conflict of interest.

\section{Acknowledgements}

This work was supported by grants from the Medical University of Lodz (\#502-03/1-156-04/502-14-239 to AW, 503/3-015-02/503-31-001 to UK, and 503/1-15604/503-11-001 to JF).

\section{REFERENCES}

Ahn K, Johnson DS, Mileni M, Beidler D, Long JZ, McKinney MK, Weerapana E, Sadagopan N, Liimatta M, Smith SE, Lazerwith S, Stiff C, Kamtekar S, Bhattacharya K, Zhang Y, Swaney S, Van Becelaere K, Stevens RC, Cravatt BF (2009) Discovery and characterization of a highly selective FAAH inhibitor that reduces inflammatory pain. Chem Biol 16: 411-420. http://doi.org/10.1016/j. chembiol.2009.02.013

Alberich Jordà M, Rayman N, Tas M, Verbakel SE, Battista N, van Lom K, Löwenberg B, Maccarrone M, Delwel R (2004) The peripheral cannabinoid receptor $\mathrm{Cb} 2$, frequently expressed on AML blasts, either induces a neutrophilic differentiation block or confers abnormal migration properties in a ligand-dependent manner. Blood 104: 526-534. http://doi.org/10.1182/blood-2003-12-4357

Bifulco M, Laezza C, Pisanti S, Gazzerro P (2006) Cannabinoids and cancer: pros and cons of an antitumour strategy. Br J Pharmacol 148: 123-135. http://doi.org/10.1038/sj.bjp.0706632

Bifulco M, Laezza C, Valenti M, Ligresti A, Portella G, DI Marzo $\mathrm{V}$ (2004) A new strategy to block tumor growth by inhibiting endocannabinoid inactivation. FASEB J 18: 1606-608. http://doi. org/10.1096/fj.04-1754fje

Björklund E, Larsson TN, Jacobsson SO, Fowler CJ (2014) Ketoconazole inhibits the cellular uptake of anandamide via inhibition of FAAH at pharmacologically relevant concentrations. PLoS One 9: e87542. http://doi.org/10.1371/journal.pone.0087542

Caffarel MM, Sarrio D, Palacios J, Guzman M, Sanchez C (2006) Delta9-tetrahydrocannabinol inhibits cell cycle progression in human breast cancer cells through Cdc2 regulation. Cancer Res 66: 66156621. http://doi.org/10.1158/0008-5472.CAN-05-4566

Chicca A, Marazzi J, Nicolussi S, Gertsch J (2012) Evidence for bidirectional endocannabinoid transport across cell membranes. I Biol Chem 287: 34660-34682. http://doi.org/10.1074/jbc.M112.373241
Cianchi F, Papucci L, Schiavone N, Lulli M, Magnelli L, Vinci MC, Messerini L, Manera C, Ronconi E, Romagnani P, Donnini M, Perigli G, Trallori G, Tanganelli E, Capaccioli S, Masini E (2008) Cannabinoid receptor activation induces apoptosis through tumor necrosis factor alpha-mediated ceramide de novo synthesis in colon cancer cells. Clin Cancer Res 14: 7691-7700. http://doi. org/10.1158/1078-0432.CCR-08-0799

Cipriano M, Haggstrom J, Hammarsten P, Fowler CJ (2013) Association between cannabinoid $\mathrm{CB}(1)$ receptor expression and Akt signalling in prostate cancer. PLoS One 8: e65798. http://doi. org/10.1371/journal.pone.0065798

Cudaback E, Marrs W, Moeller T, Stella N (2010) The expression level of $\mathrm{CB} 1$ and $\mathrm{CB} 2$ receptors determines their efficacy at inducing apoptosis in astrocytomas. PLoS One 5: e8702. http://doi. org/10.1371/journal.pone.0008702

Day TA, Rakhshan F, Deutsch DG, Barker EL (2001) Role of fatty acid amide hydrolase in the transport of the endogenous cannabinoid anandamide. Mol Pharmacol 59: 1369-1375

De Lago E, Gustafsson SB, Fernandez-Ruiz J, Nilsson J, Jacobsson SO, Fowler CJ (2006) Acyl-based anandamide uptake inhibitors cause rapid toxicity to $\mathrm{C} 6$ glioma cells at pharmacologically relevant concentrations. J Neurochem 99: 677-688. http://doi.org/10.1111/ j.1471-4159.2006.04104.x

Devane WA, Hanus L, Breuer A, Pertwee RG, Stevenson LA, Griffin G, Gibson D, Mandelbaum A, Etinger A, Mechoulam R (1992) Isolation and structure of a brain constituent that binds to the cannabinoid receptor. Science 258: 1946-1949

Ek S, Hogerkorp CM, Dictor M, Ehinger M, Borrebaeck CA (2002) Mantle cell lymphomas express a distinct genetic signature affecting lymphocyte trafficking and growth regulation as compared with subpopulations of normal human B cells. Cancer Res 62: 4398-4405

Endsley MP, Aggarwal N, Isbell MA, Wheelock CE, Hammock BD, Falck JR, Campbell WB, Nithipatikom K (2007) Diverse roles of 2-arachidonoylglycerol in invasion of prostate carcinoma cells: Location, hydrolysis and 12-lipoxygenase metabolism. Int J Cancer 121: 984-991. http://doi.org/10.1002/ijc.22761

Fowler CJ (2013) Transport of endocannabinoids across the plasma membrane and within the cell. FEBS J 280: 1895-1904. http://doi. org/10.1111/febs.12212

Gerard CM, Mollereau C, Vassart G, Parmentier M (1991) Molecular cloning of a human cannabinoid receptor which is also expressed in testis. Biochem J 279: 129-134

Gustafsson SB, Palmqvist R, Henriksson ML, Dahlin AM, Edin S, Jacobsson SO, Öberg $\AA$, Fowler CJ (2011) High tumour cannabinoid $\mathrm{CB} 1$ receptor immunoreactivity negatively impacts disease-specific survival in stage II microsatellite stable colorectal cancer. PLoS One 6: e23003. http://doi.org/10.1371/journal.pone.0023003

Hansen MB, Nielsen SE, Berg K (1989) Re-examination and further development of a precise and rapid dye method for measuring cell growth/cell kill. J Immunol Methods 119: 203-210

Hofmann NA, Barth S, Waldeck-Weiermair M, Klec C, Strunk D, Malli R, Graier WF (2014) TRPV1 mediates cellular uptake of anandamide and thus promotes endothelial cell proliferation and network-formation. Biol Open 12: 1164-1172. http://doi.org/10.1242/ bio. 20149571.

Islam TC, Asplund AC, Lindvall JM, Nygren L, Liden J, Kimby E, Christensson B, Smith CI, Sander B (2003) High level of cannabinoid receptor 1 , absence of regulator of $G$ protein signalling 13 and differential expression of Cyclin D1 in mantle cell lymphoma. Leukemia 17: 1880-1890. http://doi.org/10.1038/sj.leu.2403057

Jung CK, Kang WK, Park JM, Ahn HJ, Kim SW, Taek Oh S, Choi KY (2013) Expression of the cannabinoid type I receptor and prognosis following surgery in colorectal cancer. Oncol Lett 5: 870-876. http://doi.org/10.3892/ol.2012.1081

Kelly H, Goldberg RM (2005) Systemic therapy for metastatic colorectal cancer: current options, current evidence. J Clin Oncol 20: 45534560. http://doi.org/10.1200/JCO.2005.17.749

Laezza C, Pisanti S, Malfitano AM, Bifulco M (2008) The anandamide analog, Met-F-AEA, controls human breast cancer cell migration via the RHOA/RHO kinase signaling pathway. Endocr Relat Cancer 15: 965-974. http://doi.org/10.1677/ERC-08-0030

Lewandowska U, Szewczyk K, Owczarek K, Hrabec Z, Podsędek A, Koziołkiewicz M, Hrabec E (2013) Flavanols from Japanese quince (Chaenomeles japonica) fruit inhibit human prostate and breast cancer cell line invasiveness and cause favorable changes in $\mathrm{Bax} / \mathrm{Bcl}-2$ mRNA ratio. Nutr Cancer 65: 273-285. http://doi.org/10.1080/016 35581.2013.749292

Liu J, Wang L, Harvey-White J, Huang BX, Kim HY, Luquet S, Palmiter RD, Krystal G, Rai R, Mahadevan A, Razdan RK, Kunos $G$ (2008) Multiple pathways involved in the biosynthesis of anandamide. Neuropharmacology 54: 1-7. http://doi.org/10.1016/j.neuropharm.2007.05.020

Massi P, Vaccani A, Ceruti S, Colombo A, Abbracchio MP, Parolaro D (2004) Antitumor effects of cannabidiol, a nonpsychoactive cannabinoid, on human glioma cell lines. J Pharmacol Exp Ther 308: 838-845. http://doi.org/10.1124/jpet.103.061002 
Matas D, Juknat A, Pietr M, Klin Y, Vogel Z (2007) Anandamide protects from low serum-induced apoptosis via its degradation to ethanolamine. J Biol Chem 282: 7885-7892. http://doi.org/10.1074/jbc. M608646200

Matsuda LA, Lolait SJ, Brownstein MJ, Young AC, Bonner TI (1990) Structure of a cannabinoid receptor and functional expression of the cloned cDNA. Nature 346: 561-564. http://doi. org $/ 10.1038 / 346561 \mathrm{a} 0$

Mechoulam R, Ben-Shabat S, Hanus L, Ligumsky M, Kaminski NE, Schatz AR, Gopher A, Almog S, Martin BR, Compton DR (1995) Identification of an endogenous 2-monoglyceride, present in canine gut, that binds to cannabinoid receptors. Biochem Pharmacol 50: 83-90

Munro S, Thomas KL, Abu-Shaar M (1993) Molecular characterization of a peripheral receptor for cannabinoids. Nature 365: 61-65. http://doi.org/10.1038/365061a0

Nithipatikom K, Endsley MP, Isbell MA, Falck JR, Iwamoto Y, Hillard CJ, Campbell WB (2004) 2-arachidonoylglycerol: a novel inhibitor of androgen-independent prostate cancer invasion. Cancer Res 64: 8826-8830. http://doi.org/10.1158/0008-5472.CAN-04-3136

Pertwee RG (2006) The pharmacology of cannabinoid receptors and their ligands: an overview. Int J Obes (Lond) 30 (Suppl 1): S13-S18. http://doi.org/10.1038/sj.ijo.0803272

Ralevic V, Kendall DA, Jerman JC, Middlemiss DN, Smart D (2001) Cannabinoid activation of recombinant and endogenous vanilloid receptors. Eur J Pharmacol 424: 211-219
Ranger JJ, Levy DE, Shahalizadeh S, Hallett M, Muller WJ (2009) Identification of a Stat3-dependent transcription regulatory network involved in metastatic progression. Cancer Res 69: 6823-6830. http://doi.org/10.1158/0008-5472.CAN-09-1684

Reggio PH, Traore H (2000) Conformational requirements for endocannabinoid interaction with the cannabinoid receptors, the anandamide transporter and fatty acid amidohydrolase. Chem Phys Lipids 108: $15-35$

Rudolph MI, Boza Y, Yefi R, Luza S, Andrews E, Penissi A, Garrido P, Rojas IG (2008) The influence of mast cell mediators on migration of SW756 cervical carcinoma cells. J Pharmacol Sci 106: 208-218

Steward BW, Wild CP (2014) World Cancer Report. World Health Organisation

Vaccani A, Massi P, Colombo A, Rubino T, Parolaro D (2005) Cannabidiol inhibits human glioma cell migration through a cannabinoid receptor-independent mechanism. Br J Pharmacol 144: 1032-1036. http://doi.org/10.1038/sj.bjp.0706134

Wang D, Wang H, Ning W, Backlund MG, Dey SK, DuBois RN (2008) Loss of cannabinoid receptor 1 accelerates intestinal tumor growth. Cancer Res 68: 6468-6476. http://doi.org/10.1158/00085472.CAN-08-0896.

Ye L, Zhang B, Seviour EG, Tao KX, Liu XH, Ling Y, Chen JY, Wang GB (2011) Monoacylglycerol lipase (MAGL) knockdown inhibits tumor cells growth in colorectal cancer. Cancer Lett 307: 6-17. http://doi.org/10.1016/j.canlet.2011.03.007 